\title{
THE ICE SLIDE ON THE GLACIER DU TOUR
}

\author{
By R. M. GlaisteR
}

ON the afternoon of Sunday, I4 August 1949, we had climbed up the slopes of the Tête de la Jorette ( $1700 \mathrm{~m}$.) from the hamlet of Le Tour in the Chamonix valley (Haute Savoie, France) and had a full view of the Glacier du Tour opposite. All the afternoon small blocks of ice had been falling from the lowest portion of the glacier snout. At $14.00 \mathrm{hr}$. we noticed a narrow semicircular crack running from the right-hand bank of the glacier to the centre. This is just visible in Fig. I (p. 492) and is shown in the sketch map in Fig. 2 below. The crack was at a point where the slope of the glacier bed increased considerably, at a height of $2200 \mathrm{~m}$. and lay well in front of the more level firn basin at a height of about $2700 \mathrm{~m}$. A little below the point at which we saw the crack the ice passes into an ice fall over a cliff the steepest angle of which is about $50-60^{\circ}$. Each time we looked at it for the next two hours the crack appeared a little wider and stood out a deep blue against the white ice. At $16.45 \mathrm{hr}$. the crack widened appreciably, and, as we watched, the whole

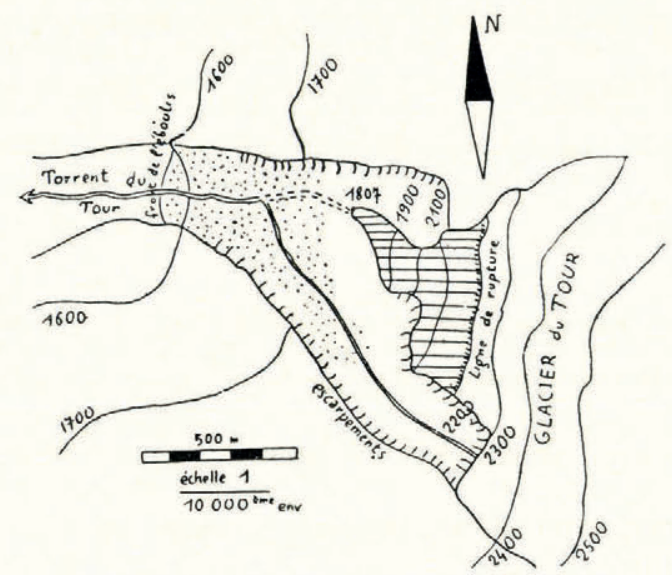

Fig. 2. Sketch-plan of the Glacier du Tour after the slide. (By courtesy of the Editors of "Géographie Alpine," Grenoble)

lower mass of the glacier moved forward and gathered speed. As it passed down the increasingly steep slope to the ice fall the ice broke into colossal blocks and poured down the precipitous slope with a noise like heavy, continuous thunder (Fig. 3, p. 492). A few seconds later, as the ice reached the terminal moraine a cloud of ice particles rose and completely obscured the view for some thirty seconds during which a blast of cold air reached us from across the valley (Fig. 4, p. 493).

At the north side (left-hand side in the photographs) a true rainbow of about $45^{\circ}$ of arc appeared. This is interesting as it shows that the ice particles, presumably of irregular shapes, must have melted, forming spherical drops, the latent heat being supplied by the warm air of the valley. This is what would be expected since small particles have a large surface to volume ratio.

Fig. 5 (p. 493) shows the glacier when movement had ceased and the cloud had dispersed. The weight of ice that fell was estimated at half a million tons,* equivalent to some forty years' accumulation. The ice from the slide engulfed nine people who were picnicking on the moraine. This was the most disastrous slide that had occurred in the French Alps since that of the Glacier de Tête-Rousse in July 1892 which claimed 125 victims.

* Other accounts make this figure considerably higher.-Ed. 
Since glacier slides on this scale must necessarily be rare occurrences it is interesting to see whether any meteorological explanation can be found in this case. I am indebted to Professor P. Veyret of the Institut de Géographie Alpine of Grenoble for the information in the following tables.

\begin{tabular}{|c|c|c|c|c|c|c|c|c|c|}
\hline \multicolumn{10}{|c|}{ Mean temperatures $\left({ }^{\circ} \mathrm{C}.\right)$ at Le Tour ( $1460 \mathrm{~m}$.) } \\
\hline & Year & & & I 944 & ' 945 & 1946 & I947 & I 948 & I949 \\
\hline $\begin{array}{l}\text { June, July, } \\
\text { August }\end{array}$ & $\begin{array}{c}\text { August } \\
\ldots\end{array}$ & $\begin{array}{l}. \\
\ldots\end{array}$ & $\begin{array}{l}\cdots \\
\ldots\end{array}$ & $\begin{array}{l}13.8 \\
16.1\end{array}$ & $\begin{array}{l}13.2 \\
18.0\end{array}$ & $\overline{18 \cdot 0}$ & $\begin{array}{l}16.6 \\
18.5\end{array}$ & - 3.9 & $\begin{array}{l}13.9 \\
14.7\end{array}$ \\
\hline
\end{tabular}

TABle II

\begin{tabular}{|c|c|c|c|c|c|c|c|c|c|}
\hline & & Day & perat & $\left({ }^{\circ} \mathrm{C}\right.$. & e T & Augu & 949 & & \\
\hline Day & & 10 & II & 12 & 13 & $14^{*}$ & 15 & I6 & 17 \\
\hline $\begin{array}{l}\text { Minimum }{ }^{\circ} \mathrm{C} . \\
\text { Maximum }^{\circ} \mathrm{C} \text {. }\end{array}$ & $\cdots$ & $\begin{array}{l}\text { I } 35 \\
225\end{array}$ & $\begin{array}{r}85 \\
205\end{array}$ & $\begin{array}{r}3 \\
19\end{array}$ & $\begin{array}{r}1 \\
14\end{array}$ & $\begin{array}{r}I \\
16\end{array}$ & $\begin{array}{r}5 \\
2 I\end{array}$ & $\begin{array}{r}7 \\
22\end{array}$ & $\begin{array}{c}6 \\
22 \cdot 5\end{array}$ \\
\hline
\end{tabular}

Table I shows that although the summer of 1949 was hotter than that of 1948 it was actually cooler than those of the preceding years. However, from the minimum and maximum daily temperatures of the month (Table II) it is seen that the slide occurred in the middle of a cold spell with a minimum of $\mathrm{I}^{\circ} \mathrm{C}$. at $\mathrm{I} 450 \mathrm{~m}$. on the day of the slide. On the basis of the I.C.A.N. dry adiabatic lapse rate of $1 \cdot 98^{\circ} \mathrm{C}$. $/ 1000 \mathrm{ft} .\left(6 \cdot 5^{\circ} \mathrm{C} . / \mathrm{km}\right.$.) this means a minimum of $-4^{\circ} \mathrm{C}$. at the height of the breakaway, $2200 \mathrm{~m}$. The cause of the slide is thus most probably to be found in the succession of warm days and cold nights which preceded the occurrence. This would cause repeated melting and freezing (expansion) of the ice in the glacial cracks thus driving the lower part of the glacier forward with a wedge or ratchet-like action into an unstable position. $\dagger$

MS. received 8 fune $195 \circ$

† Mons. P. Guichonnet in an account of the slide in the Revue de Géographie Alpine, Grenoble (Tome 38 , Fasc. 4 , 1950, p. 198-201), reaches the same conclusion, but suggests that the very hot summer of r 947 may have loosened the
adhesion of the glacier sole.

Another factor was suggested by Mons. Messines du Sourbier, President of the Glaciological Sub-section of the Société Hydrotechnique de France (Mémoires et Travaux, Vol. 1, 1950, p. 56-60). According to this the recent recession of the glacier had brought the snout out of a gully in which it lay firm thus damming the ice stream, on to a steep open-
faced cliff above and so removing the dam.

The two accounts quoted in this note provide certain other details to which those interested are referred.- $-E d$.

\section{THE INTERNATIONAL SNOW CLASSIFICATION}

Ar its meeting in Oslo in 1948 the International Commission on Snow and Glaciers passed a resolution that "attempts should be made to standardize a system of snow cover measurement." As a preliminary step a Committee was set up to consider a suitable classification of snow. Its members were Mr. V. J. Schaefer (United States), Mr. G. J. Klein (Canada) and Dr. M. de Quervain (Switzerland).

In the autumn of 1949 the Committee produced a tentative snow classification, the aim of which was "to promote uniformity in the method of describing snow and to simplify the correlation of data obtained by different groups." Comments and suggestions were invited for improving it, and the tentative form was put into operation for a time in America in order to expose any flaws.

The Committee sent this classification to the British Glaciological Society requesting comments and criticisms. A Meeting of the Society was accordingly arranged and took place in May 


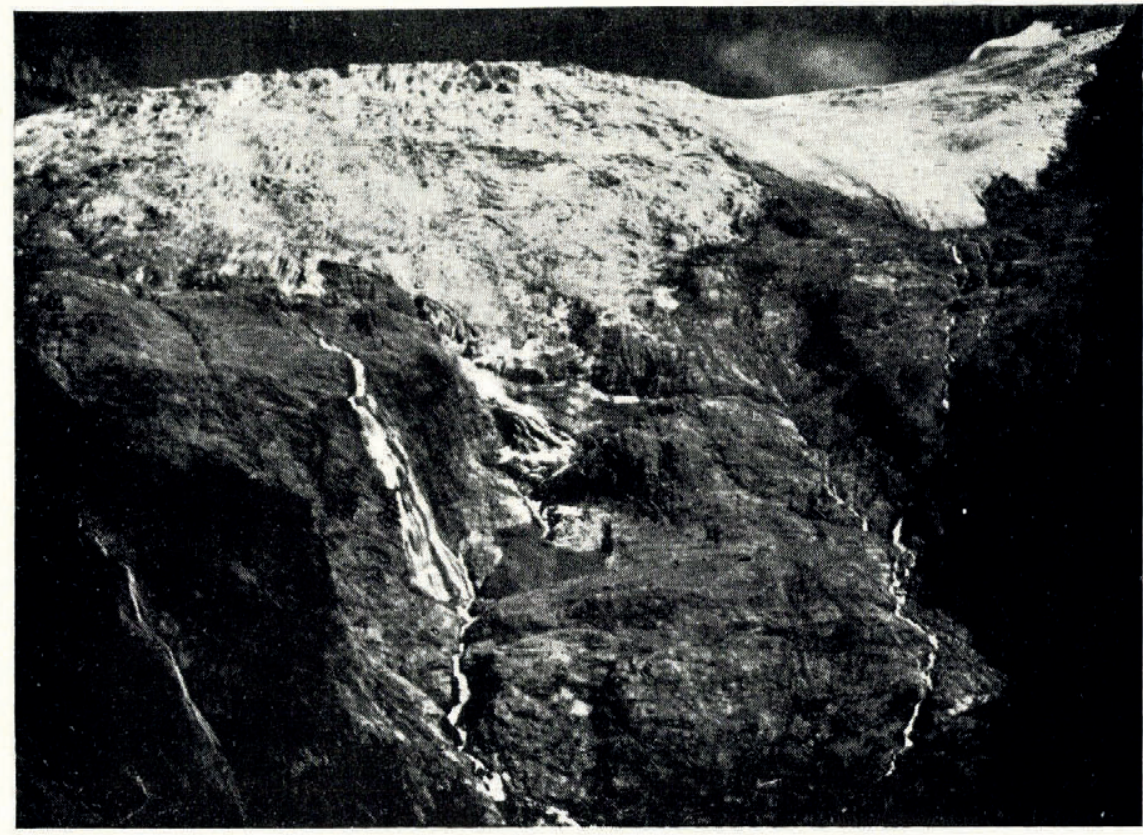

Fig. I. The glacier just before the slide

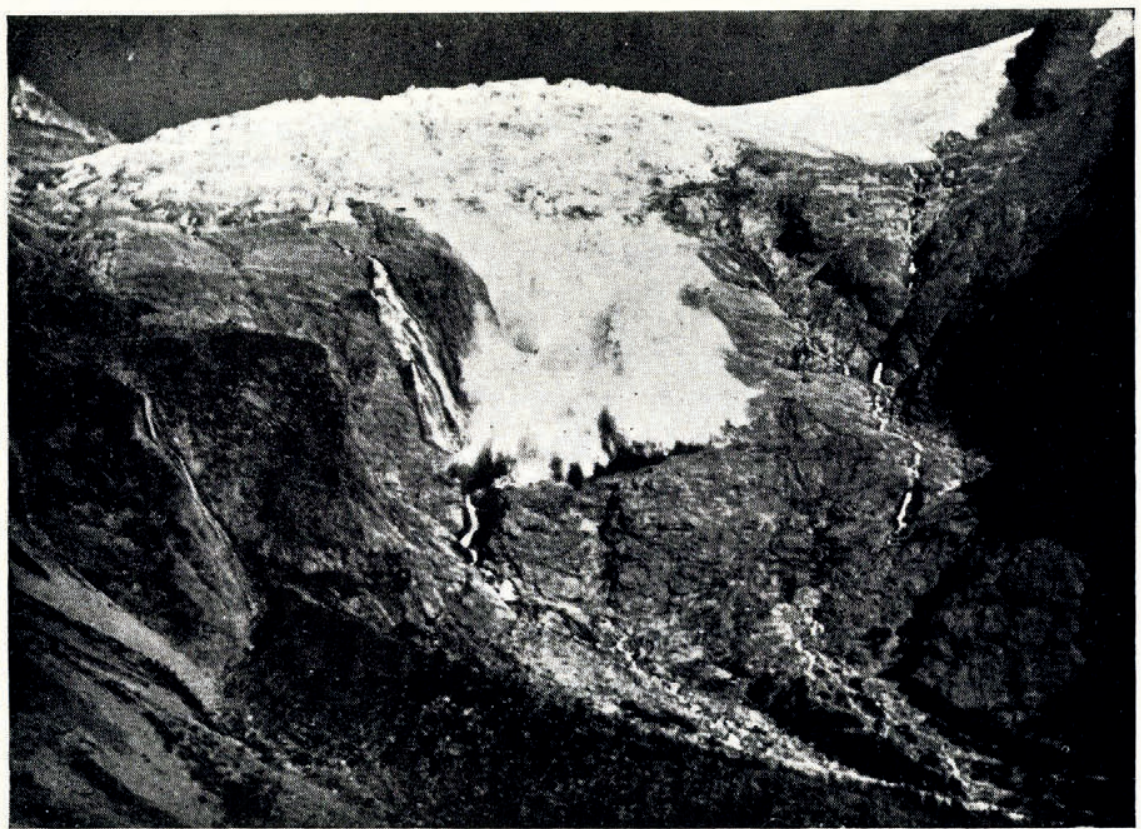

Fig. 3. The commencement of the slide

The Glacier du Tour ice slide (see text, p. 508 et seq.) 


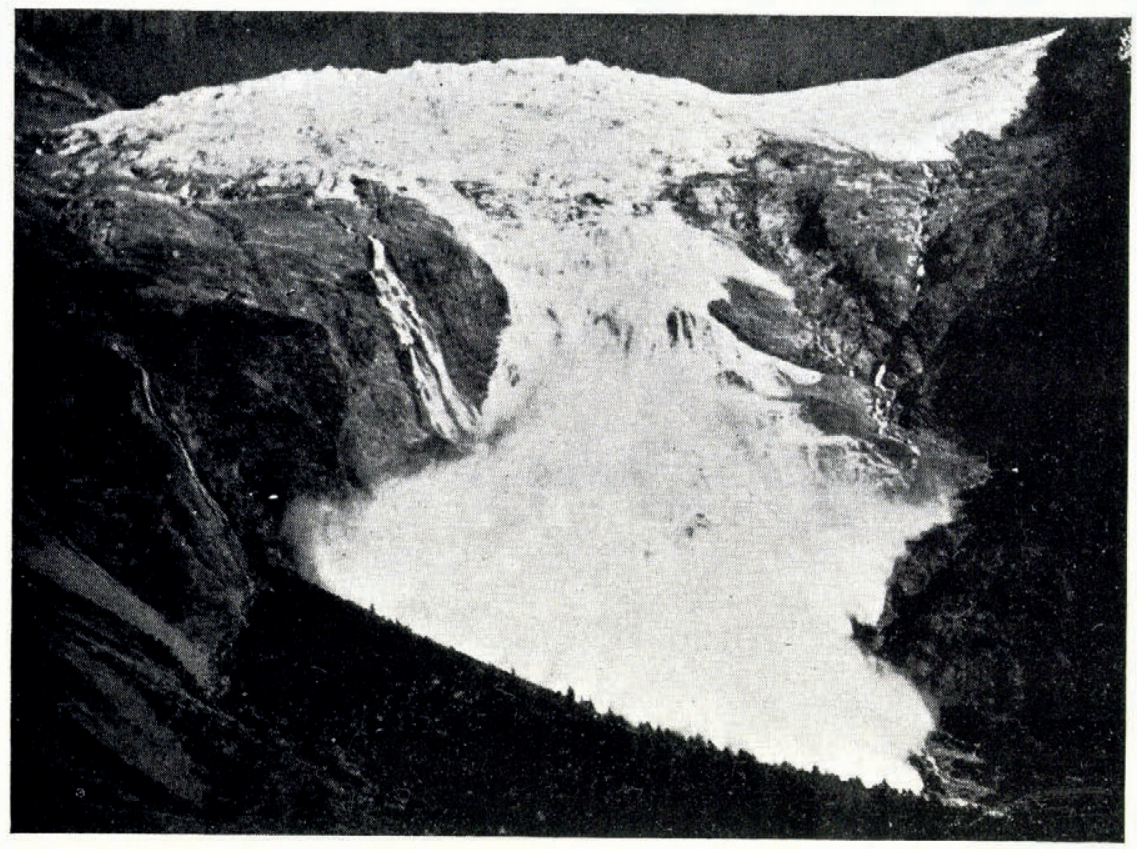

Fig. 4. The ice cloud a few seconds later

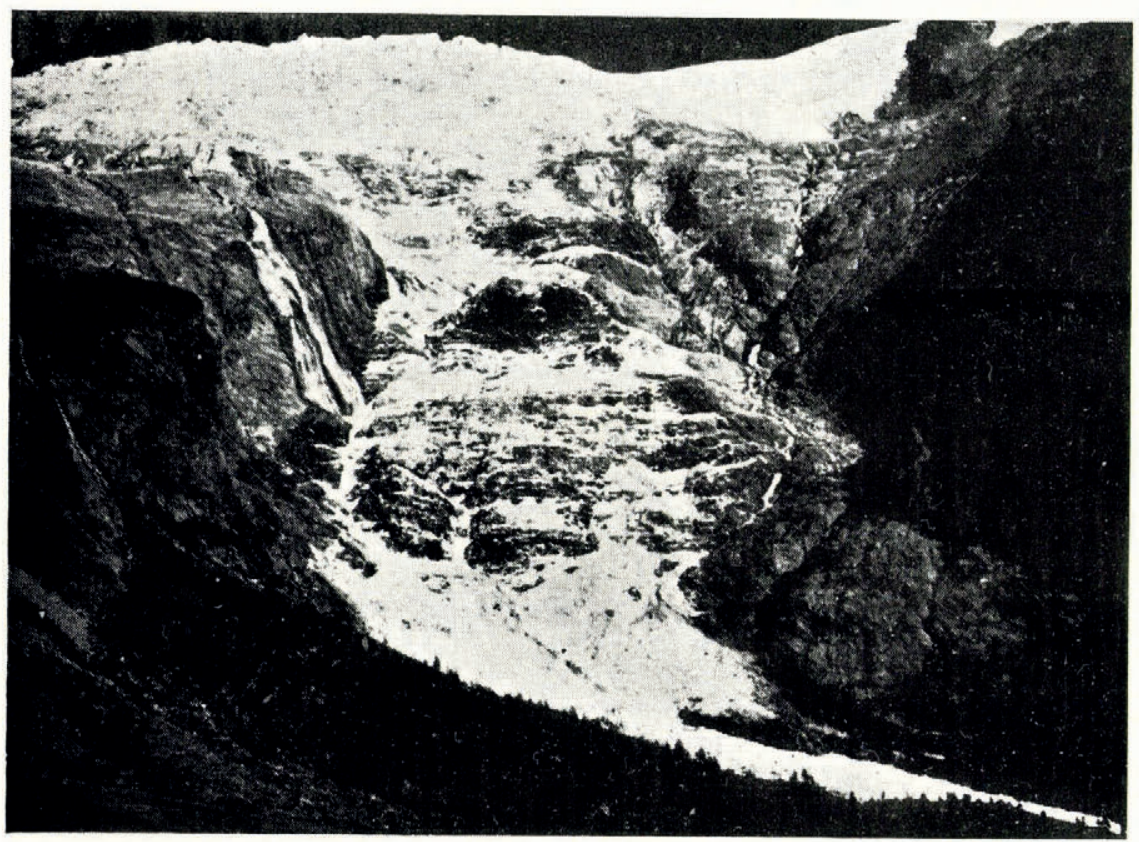

Fig. 5. The glacier at the end of the slide

Photographs by R. M. Glaister, reproduced by courtesy of the Editors of "Weather" 